\title{
Assessment of Dispersion of Oxide of Nitrogen using AERMOD over a Tropical Industrial Region
}

\author{
Rahul Boadh \\ Centre for oceans, Rivers, \\ Atmosphere and Land \\ Sciences (CORAL), \\ Indian Institute of Technology \\ Kharagpur, \\ Kharagpur -721302, \\ West Bengal, India.
}

\author{
A.N.V. Satyanarayana \\ Centre for oceans, Rivers, \\ Atmosphere and Land \\ Sciences (CORAL), \\ Indian Institute of Technology \\ Kharagpur, \\ Kharagpur-721302, \\ West Bengal, India.
}

\author{
T.V.B.P.S. Rama Krishna \\ Environmental Impact \& Risk \\ Assessment Division, \\ CSIR- National Environmental \\ Engineering Research \\ Institute, \\ Nagpur -440020 \\ Maharashtra, India
}

\begin{abstract}
Accurate representation of dispersion of air pollutants is essential for environmental management and planning purposes. In the present study, an attempt has been made to investigate the improvement of pollution dispersion using AERMOD model which includes atmospheric boundary layer processes explicitly. Ranchi region, a fast growing urban city with industries and vehicular pollution in the Jharkhand state of India is chosen. Surface micro-meteorological tower data and upper air radiosonde observations are utilized in the study. Surface boundary layer parameters such as friction velocity and sensible heat flux used as input to AERMOD model are obtained from flux-profile relationships and validated with turbulence measurements. The pollutant concentrations includes industrial as well as vehicular sources predicted by AERMOD are validated with the ambient air quality data of Central Pollution Control Board at Ranchi. Results reveal that AERMOD performed well in representing air pollution dispersion over Ranchi region.
\end{abstract}

\section{General Terms AERMOD}

\section{Keywords}

Air Pollution, Dispersion Model and Atmospheric boundary layer

\section{INTRODUCTION}

Air pollution has been existing since the first fire was lit and is considered to have considerable influence on the global environment. In many countries with ambitious economic growth targets, the acceptable levels of air pollution have been transgressed, resulting in an urban skyline characterized by smog and dust clouds. In several Indian cities with population of over a million, air pollution levels exceed World Health Organization (WHO) standards. Serious respiratory diseaserelated problems have been identified for both indoor and outdoor pollution in major cities of several countries [1]. Air pollution models are routinely used in environmental impact assessments, risk analysis and emergency planning, and source apportionment studies [2]. In highly polluted cities in India such as Delhi, Kolkata and Chennai, regional scale air quality models are used to forecast air pollution. The results from these models may initiate compulsory shutdown of industries or vehicle restrictions. Various roles served by air pollution models, which cover a broad range of scales from local to global, lead to distinct modeling requirements. The emphasis is on Gaussian-plume type models for continuous releases, which are at the core of most U.S. Environmental Protection Agency (EPA) regulatory models.

[3] have studied the dispersion of pollutants in convective low wind conditions using three different dispersion models of Gaussian type, over few places in Delhi and found that the transport and dispersion of pollutants becomes weak under low wind conditions, resulting in large ground level concentrations (GLC). [4] have examined a point source plume at high altitudes using a modified Gaussian model. [5] have estimated assimilative capacity and dispersion of pollutants due to industrial sources in Visakhapatnam bowl area by computing the GLCs of gaseous pollutants using Gaussian models. [6] have discussed the impact of an industrial complex, located in the outskirts of Hyderabad city, on the ambient air quality using ISCST-3 model.

[7] have discussed on provision of services to develop Guidance for air dispersion modeling in ISC-AERMOD view. [8] has reviewed the inter-comparison studies of AERMOD and ADMS, and discussed the output features of these models. [9] have compared the results obtained from AERMOD and ISC PRIME models, in which they have shown AERMOD gives the better results compared to ISCST3. [10] have used ISC-AERMOD to predict the concentration of $\mathrm{NO}_{2}$ and $\mathrm{SO}_{2}$ from a diesel power plant complex based on worse-case scenario operation.

[11] have discussed the regulatory and compliance-based modeling for air quality impact assessment for predicting future air quality under various management scenarios particularly where air quality monitoring data are limited. They have computed the concentration of $\mathrm{CO}, \mathrm{NO}_{\mathrm{X}}, \mathrm{SO}_{2}$ and $\mathrm{PM}_{10}$ at sensitive receptor locations and compared to WHO interim guidelines. [12] have studied the health hazards due to suspended particulate matter (RSPM or $\mathrm{PM}_{10}$ ) over Delhi employing AERMOD. [13] have presented a methodology for implementation of the AERMOD modeling system when local data is incomplete.

The 1-hour, 8-hour and 24-hour averages of criteria pollutants $\left(\mathrm{NO}_{2}, \mathrm{SO}_{2}, \mathrm{CO}, \mathrm{PM}_{2.5}\right.$ and PM10) monitored during 20042009 at three observational sites in Delhi were compared with the Central Pollution Control Board (CPCB) standards by [14] and emphasized the requirement of good emissions inventory and advanced modeling approaches for developing emissions control programs. 
It has been observed from literature that several dispersion models are available for studying the dispersion of air pollutants emitting from different sources such as point, vehicular or mobile, area and volume sources. As AERMOD is the latest model being used as preferred model for estimating the GLCs of pollutants, it is proposed to use AERMOD in the present study to assess the pollutant dispersion due to industrial and vehicular sources. From the literature it is also noticed that the studies regarding the performance evaluation of AERMOD in dispersion calculation are very few in India. Hence, the present study mainly focuses on evaluation of atmospheric boundary layer parameters and also validation of the GLCs computed using AERMOD with observations over Ranchi. The uniqueness in the present study includes the validation of atmospheric boundary layer variables with high resolution turbulence measurements.

\section{STUDY SITE}

Ranchi is the capital city of the newly formed state of Jharkhand, India. Ranchi is located on the eastern part of the Indian sub-continent (Fig. 1). The summer is warm but bearable with average high temperature around $37.2^{\circ} \mathrm{C}$ where as the winter is quiet pleasant with average temperature dipping up to $10.3{ }^{\circ} \mathrm{C}$. Ranchi city is located between the geographic co-ordinates $23^{\circ} 18^{\prime} 43.54^{\prime \prime} \mathrm{N}$ to $23^{\circ} 22^{\prime} 39.35^{\prime \prime} \mathrm{N}$ and $85^{\circ} 16^{\prime} 47.88^{\prime \prime} \mathrm{E}$ to $85^{\circ} 21^{\prime} 38.71$ ' E, 274.5 and 652.70 meters above sea level. The monitoring location (receptor) called as Albert Ekka Chowk (2322'11.84" N, 85¹9'30.15" W) and Industry location, namely, Usha Martin Industry $\left(23^{\circ} 22^{\prime} 06.13^{\prime \prime} \mathrm{N}, 8^{\circ} 25^{\prime} 39.61^{\prime \prime}\right.$ E) are depicted in Fig. 1.

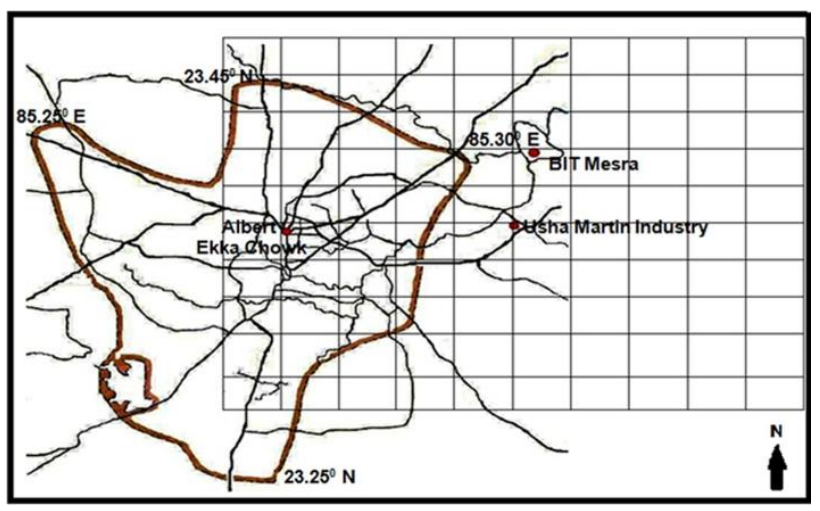

Fig. 1: Location of Industry, Ambient Air Quality Monitoring Location and Meteorological data monitoring station in the study area (Ranchi)

Average annual precipitation is 2078 millimeters with $34 \%$ of the total rainfall occurring in the month of July and monthly averages rainfall is $7.20 \mathrm{~cm}$. About $28 \%$ of Ranchi is covered by forest. The climate of Ranchi follows a typical seasonal monsoon weather pattern. The peak temperatures in April and May are as high as $35.5^{\circ} \mathrm{C}$ before monsoon.

It has a population of $2,912,022$ [15] making $46^{\text {th }}$ largest city in India. Ranchi has been under stress due to increasing urbanization and industrialization and it has become one of the industrial colonies of Jharkhand. Traffic flow is Ranchi is also high and comparable to the traffic in other major cities of India. About 0.9 million vehicles are plying on city roads during the year 2010 , of which, $80 \%$ are two wheelers while the rest fall in the category of heavy vehicles, three wheelers and four- wheelers. In addition to this are the vehicles used by the floating population.

\section{DATA USED}

The emission rates of oxides of nitrogen (NOx) emitted from the industrial sources and their source characteristics, meteorological and ambient air quality data collected during 2010 in the study area are described in this section.

\subsection{Meteorological data}

The meteorological data for 7 days $(3,5,8,12,15,19$ and 22 , April 2010) obtained from 32 meter micro-meteorological tower at Birla Institute of Technology; Mesra at Ranchi is used in the present study. The tower data consists of slow response as well as fast response data (for more details of the data and instrumentation, refer [16]. The slow response data consists of wind speed $\left(\mathrm{ms}^{-1}\right)$, wind direction (degrees), air temperature $\left({ }^{\circ} \mathrm{C}\right)$, relative humidity $(\%)$, pressure $(\mathrm{mb})$, radiation components $\left(\mathrm{Wm}^{-2}\right)$, and cloud cover (oktas). Fast response data consists of 3-D wind components $\left(\mathrm{ms}^{-1}\right)$ and temperature $\left({ }^{\circ} \mathrm{C}\right)$ with $10 \mathrm{~Hz}$ temporal resolution. Upper air observations (radiosonde data) during the study period are obtained from web-link of University of Wyoming http://weather.uwyo.edu/upperair/.

In the present study, the flux profile relationships are used to compute the boundary layer parameters such as surface friction velocity, connective velocity scale, and sensible heat flux in unstable and stable conditions.

\section{Flux profile relationships}

The wind speed $(U)$ and potential temperature $(\theta)$ on the basis of surface layer similarity theory [17], are given by:

$$
\begin{aligned}
& \mathrm{U}(\mathrm{z})=\frac{\mathrm{u}_{*}}{\mathrm{k}}\left[\ln \left(\frac{\mathrm{z}}{\mathrm{z}_{0}}\right)-\psi_{m}\left(\frac{\mathrm{z}}{\mathrm{L}}\right)+\psi_{m}\left(\frac{\mathrm{z}_{0}}{\mathrm{~L}}\right)\right] \\
& \theta(\mathrm{z})-\theta_{0}=\frac{\theta_{*}^{*}}{\mathrm{k}}\left[\ln \left(\frac{\mathrm{z}}{\mathrm{z}_{0}}\right)-\psi_{h}\left(\frac{\mathrm{z}}{\mathrm{L}}\right)+\psi_{h}\left(\frac{\mathrm{z}_{0}}{\mathrm{~L}}\right)\right]
\end{aligned}
$$

where $\mathrm{z}_{0}$ is the surface roughness length, $\mathrm{z}$ is the height above surface, $\mathrm{k}$ is the von Karman constant, $\theta_{0}$ is the potential temperature at the surface, $\mathbf{u}_{*}$ is the friction velocity, $\theta_{*}$ is the friction temperature, $\mathrm{L}$ is the Obukhov length and $\psi_{\mathrm{m}}$ and $\psi_{\mathrm{h}}$ are the stability functions:

$$
\begin{aligned}
& \psi_{\mathrm{m}}\left(\frac{\mathrm{z}}{\mathrm{L}}, \frac{\mathrm{z}_{0}}{\mathrm{~L}}\right)=\int_{\mathrm{z}_{0} / \mathrm{L}}^{\mathrm{z} / \mathrm{L}}\left[1-\phi_{\mathrm{m}}\left(\zeta^{\prime}\right)\right] \frac{d \zeta^{\prime}}{\zeta^{\prime}} \\
& \psi_{\mathrm{h}}\left(\frac{\mathrm{z}}{\mathrm{L}}, \frac{\mathrm{z}_{0}}{\mathrm{~L}}\right)=\int_{\mathrm{z}_{0} / \mathrm{L}}^{\mathrm{z} / \mathrm{L}}\left[1-\phi_{\mathrm{h}}\left(\zeta^{\prime}\right)\right] \frac{d \zeta^{\prime}}{\zeta^{\prime}}
\end{aligned}
$$

where $\mathrm{z}^{\prime}=\mathrm{z} / \mathrm{L}$ and $\phi_{m}$ and $\phi_{h}$ are the basic universal similarity functions $[18,19]$. 
The Obukhov length is defined as:

$$
\mathrm{L}=\frac{\theta_{0} \mathrm{u}^{2}}{\mathrm{~kg} \theta_{*}}
$$

where $g$ is the acceleration due to gravity.

The similarity functions are numerically solved using iterative method in unstable or convective conditions using [20] and in stable conditions using [21] profiles as discussed in [22]. The mixing height/inversion heights are computed following [23]. These parameters are to be given as input to AERMOD along with meteorological data such as wind speed, wind direction and temperature. Eddy correlation technique has been employed to obtain the observed sensible heat flux and friction velocity using fast response data of wind and temperature monitored by sonic anemometer [20,24,25]. These observed fluxes were utilized for the validation of the computed fluxes.

\subsection{Emission Data}

\subsubsection{Industrial Source}

There are about 28 stacks or point sources located in an industry at Ranchi that are considered in the present study. The sources characteristic such as stack height, internal diameter, exit velocity and exit temperature are considered along with emission (in $g s^{-1}$ ) of $\mathrm{NO}_{\mathrm{X}}$. The location $(\mathrm{X}, \mathrm{Y})$ on the Cartesian grid of these point sources is also taken. The locations of stacks on a Cartesian grid network with the centre point at $(10000 \mathrm{~m}, 10000 \mathrm{~m})$ and origin $(0,0)$ is at $\mathrm{SW}$ corner or lowest left corner of the grid network. A grid spacing of $500 \mathrm{~m}$ is used over the total grid area of $20 \mathrm{~km} \mathrm{X} 20 \mathrm{~km}$ i.e. Ranchi station and region for predicting the GLCs of $\mathrm{NO}_{\mathrm{X}}$.

\subsubsection{Vehicular Source}

Petrol/diesel driven vehicles, such as cars/taxis, two/three wheelers and buses and trucks are the major sources of pollutants such as $\mathrm{NO}_{\mathrm{X}}, \mathrm{PM}_{10}$ and $\mathrm{SO}_{2}$ in the study area. The ambient air quality data of the Ranchi were collected at Albert Ekka Chowk by CPCB, Ranchi which is a busy traffic intersection. The emissions due to vehicular traffic (treated as volume sources) have been estimated using pollutant emission factor [26], total vehicular population, average distance traveled per vehicle, fuel consumption per day and average distance of travel per liter of fuel. These values produced an emission rate $q\left(\mathrm{gs}^{-1} \mathrm{~m}^{-1}\right)$.

Emission ate $q$ of the pollutant is determined from the product of emission factor of pollutant and the number of vehicles per unit length. The latter quantity is found by dividing the rate of vehicle passage through a point by vehicle average speed:

$$
\frac{\text { Vehicles }}{\text { meter }}=\left(\frac{\text { Flow }(\text { Vehicle } / \mathrm{hr})}{\text { Averagespeed }(\mathrm{km} / \mathrm{hr}}\right)\left(\frac{\mathrm{km}}{1600 \mathrm{~m}}\right)
$$

Table 1: Emissions of NOx due to vehicles at Albert Ekka Chowk (monitoring location) in Ranchi.

\begin{tabular}{|c|c|c|c|}
\hline $\begin{array}{c}\text { Type of } \\
\text { vehicle }\end{array}$ & $\begin{array}{c}\text { No of } \\
\text { vehicles } \\
\text { per } \\
\text { hour }\end{array}$ & $\begin{array}{c}\text { Emission } \\
\text { Factor } \\
\left(\mathbf{g k m}^{-1} \mathbf{v e h}^{-1}\right)\end{array}$ & $\begin{array}{c}\text { Emission Rate (gs } \\
\mathbf{1} \text { ) }\end{array}$ \\
\hline $\begin{array}{c}\text { Two Wheelers } \\
\text { (petrol) }\end{array}$ & 200 & 0.54 & 0.015 \\
\hline $\begin{array}{c}\text { Three wheelers. } \\
\text { (diesel) }\end{array}$ & 150 & 1.47 & 0.031 \\
\hline Car (petrol) & 100 & 1.13 & 0.016 \\
\hline MUV(diesel) & 50 & 2.46 & 0.017 \\
\hline Bus (diesel) & 50 & 15.25 & 0.106 \\
\hline Truck (diesel) & 50 & 13.84 & 0.096 \\
\hline LVC(diesel) & 50 & 2.48 & 0.017 \\
\hline Total & & & $\mathbf{0 . 2 9 8}$ \\
\hline
\end{tabular}

\section{METHODOLOGY}

A brief description of the AERMOD, for computing GLCs of pollutant due to industrial and vehicular sources in Ranchi is given.[27] has discussed the formulation of the American Meteorological Society (AMS) and U.S. Environmental Protection Agency (EPA) Regulatory Model (AERMOD) Improvement Committee's applied air dispersion model. A comprehensive description of the AERMOD dispersion model formulations, including AERMOD's characterization of the boundary layer, the representative terrain used to influence flow and the specification of model dispersion algorithms for both convective and stable conditions in urban and rural areas are given.

A notable strength of AREMOD's formulations, particularly in the characterization of the boundary layer, lies in its reliance on previously successful modeling approaches that have been established in the literature, coupled with the developers' efforts to avoid major discontinuities that are often found in atmospheric dispersion models. The computerization flow chart of AERMOD model given in figure 2 , in this figure we are seeing that working process of the AERMOD model.

The concentrations of the pollutants are computed using equation (7) in AERMOD model [28]:

$$
\begin{aligned}
& C(X, Y, Z)=\frac{Q}{2 \pi \sigma_{Y} \sigma_{Z}} \times \exp \left(-\left(\frac{y^{2}}{2 \times \sigma_{y}^{2}}\right)\right) \\
& \times\left[\exp \left(-\frac{\left(z-H_{e f f}\right)}{2 \times \sigma_{z}^{2}}\right)+\exp \left(-\frac{\left(z+H_{e f f}\right)}{2 \times \sigma_{z}^{2}}\right)\right]
\end{aligned}
$$

The vehicular data along with pollutant emission rates are given in Table 1 


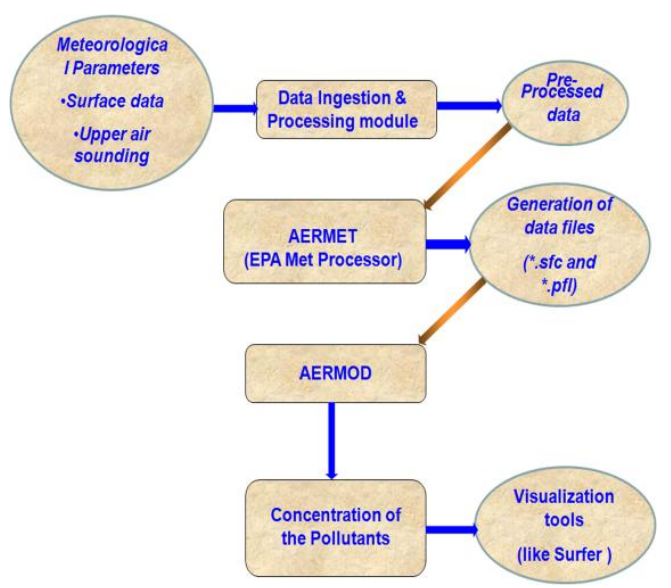

Fig.2 Flow Chart of AERMOD model

where $c(x, y, z)=$ concentration at $\mathrm{x}, \mathrm{y}, \mathrm{z} ; \quad u=$ wind speed (downwind, $m s^{-1}$ ); $\square_{y}$ and $\square_{z}=$ standard deviation of concentration in $y$ and $x ; Q=$ emission $\left(g s^{-1}\right)$ and $H_{\text {eff }}=$ effective stack height

One of the important conservation equations used in this model is as follows:

$$
C=\left(\frac{Q f}{u\left(\sigma_{z} \sqrt{2 \pi}\right.}\right)\left(\frac{g_{1}+g_{2}+g_{3}}{\sigma_{z} \sqrt{2 \pi}}\right)
$$

where

$$
\mathrm{f}=\text { crosswind dispersion parameter }=\exp \left(-\frac{y^{2}}{2 \sigma_{y}^{2}}\right)
$$

$\mathrm{g}=$ vertical dispersion parameter $=\mathrm{g}_{1}+\mathrm{g}_{2}+\mathrm{g}_{3}$

$\mathrm{g}_{1}=$ vertical dispersion with no reflection

$$
=\exp \left(-\frac{(z-H)^{2}}{2 \sigma_{z}^{2}}\right)
$$

$\mathrm{g}_{2}=$ vertical dispersion due to reflection from the ground

$$
=\exp \left(-\frac{(z+H)^{2}}{2 \sigma_{z}^{2}}\right)
$$

$\mathrm{g}_{3}=$ vertical dispersion due to reflection from inversion led aloft $=\sum(\mathrm{A}+\mathrm{B}+\mathrm{AA}) \mathrm{BB}$

$$
\begin{aligned}
& A=\exp \left(-\frac{(z-H-2 M L)^{2}}{2 \sigma_{z}^{2}}\right) \\
& B=\exp \left(-\frac{(z+H+2 M L)^{2}}{2 \sigma_{z}^{2}}\right) \\
& A A=\exp \left(-\frac{(z+H-2 M L)^{2}}{2 \sigma_{z}^{2}}\right) \\
& B B=\exp \left(-\frac{(z-H+2 M L)^{2}}{2 \sigma_{z}^{2}}\right)
\end{aligned}
$$

$C=$ concentration of emissions $\left(\mathrm{gm}^{-3}\right)$, at any receptor located at:

$x=$ meter downwind from the emission source point $y=$ meter crosswind from the emission source point

$z=$ meters above ground level

$Q=$ source pollutant emission rate, $g / s$

$u=$ horizontal wind velocity along the plume centerline, $m s^{-1}$

$\sigma_{z}=$ vertical standard deviation of the emission distribution, $m$

$\sigma_{y}=$ horizontal standard deviation of the emission distribution, $m$

$H=$ emission plume centerline above ground level, $m$

$L=$ distance from ground level to bottom of the inversion, $m$

The sum of the four exponential terms in $g_{3}$ converge quite rapidly, for most cases, the summation of the series with $m=1$, $\mathrm{m}=2$ and $\mathrm{m}=3$ will provide an adequate evaluation of the series. It should be noted that $\sigma_{z}$ and $\sigma_{y}$ are functions of the downwind distance to the receptor.

\section{Input and output parameters for AERMOD}

AERMOD model uses boundary layer parameter such as sensible heat flux, friction velocity, connective scale velocity, Obukhov length, roughness length, albedo, Bowen ratio and meteorological hourly data such as wind speed, temperature and wind direction. The source characteristics and emission rate of pollutants along with receptor location are also input to the model. The model generates the output in terms of hourly concentration of air pollutants at designated grid location and at discrete receptors.

\section{RESULTS AND DISCUSSION}

The ground level concentration (GLCs) of $\mathrm{NO}_{\mathrm{X}}$ due to an industrial complex in Ranchi was computed using AERMOD. The model is run on 24 hour basis and the results obtained for three days $(5,12,22$ April 2010) are presented in this study. The comparison of computed and observed boundary layer parameters and AERMOD estimated GLCs of pollutants on 24 hourly average basis and the validation with observed concentrations are presented in this section.

\subsection{Variation of wind speed and direction during the study period}

A fair estimate of the dispersion of pollutants in the atmosphere is possible based on the frequency distribution of wind direction as well as wind speed [29]. Figures $3 a, 3 b$ and $3 \mathrm{c}$ showing the wind roses depict the diurnal variation of wind speed and wind direction for 5, 12 and 22 April 2010, respectively. Calm winds of the magnitude less than $1 \mathrm{~ms}^{-1}$ are noticed during early morning and night time on 5 April 2010 as seen in Fig 3a. A maximum wind speed of about $4.2 \mathrm{~ms}^{-1}$ is noticed at $14 \mathrm{~h} \mathrm{LT}$.

The winds are observed to be predominant from NW and WNW directions on 5 and 12 April respectively where as on 22 April winds are blowing mostly from SSW followed by SW and WSW directions. Variable wind directions are noticed on 5 and 12 April. The wind speed varies between 0.5 $\mathrm{ms}^{-1}$ and $4.2 \mathrm{~ms}^{-1}$ in all days. 
a)

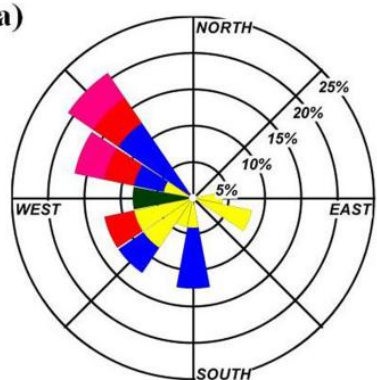

c)
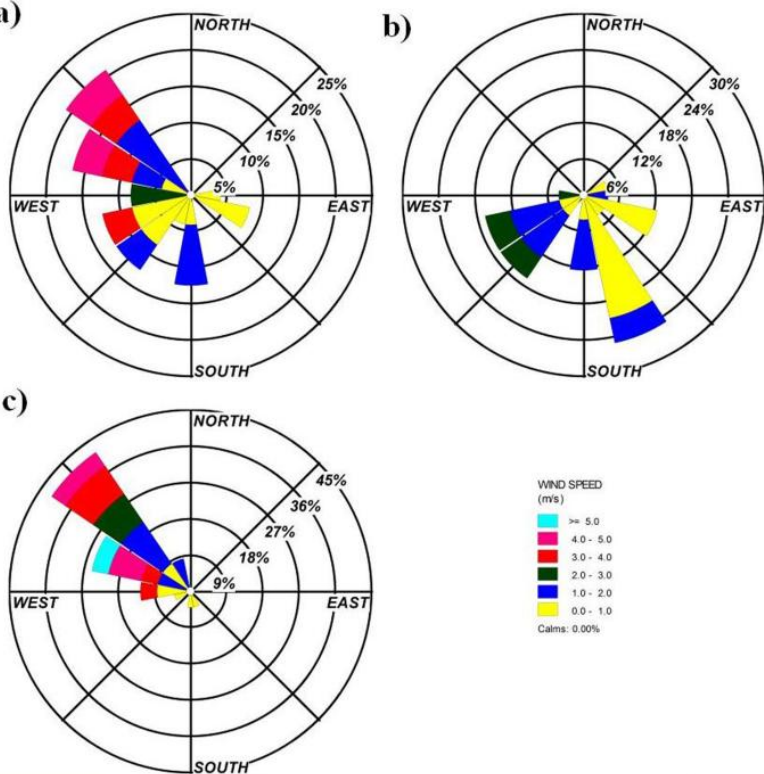

b)

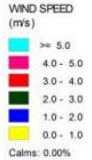

Figure 3: Wind roses for a) 5 April, (b) 12 April and (c) 22 April, 2010 respectively over Ranchi.

\subsection{Validation of computed boundary layer parameters}

In this section, the estimated atmospheric boundary layer parameters such as friction velocity and sensible heat flux required for AERMOD as input data are obtained using flux profile relationships with that of observed values obtained using eddy correlation as explained in Section 4.1.

Figure 4 illustrates the validation of diurnal variation of computed (Fig.4b) friction velocity and the observed (Fig.4a) values during 5, 12 and 22 April 2010. The range of computed friction velocity on 5 April (Fig. 4b) is 0.02 to $0.85 \mathrm{~ms}^{-1}$ where as the observed friction velocity (Fig.4a) is from 0.15 to $0.58 \mathrm{~ms}^{-1}$. The computed friction velocity values show slightly higher during day time and slightly under-estimated during night time compared to observed values on 5 April 2010. It is noticed that the range of the computed friction velocity is $0.003 \mathrm{~ms}^{-1}$ to $0.55 \mathrm{~ms}^{-1}$ and the observed range is $0.18 \mathrm{~ms}^{-1}$ to $0.52 \mathrm{~ms}^{-1}$ on 12 April (Fig. 4b).

The computed and observed friction velocity is in good agreement during day and night time on 12 April 2010. But the range of the computed and observed friction velocity on 12 April 2010 (Fig. 4b and 4a) are respectively $0.11 \mathrm{~ms}^{-1}$ to $0.98 \mathrm{~ms}^{-1}$ and $0.13 \mathrm{~ms}^{-1}$ to $0.61 \mathrm{~ms}^{-1}$. It is observed that friction velocity is higher compared to observations during the day time on 22 April 2010. Both the computed and observed values suggests moderate to strong mechanical turbulence during day time and weak turbulence during night time on all three days. Friction velocity variation is proportional to the wind speed. It is expected that the higher the wind speed the more is the friction velocity. Thus higher friction velocity is noticed on 5 and 22 April 2010 as winds are observed to be moderate to strong as shown in Fig.3.

The comparison of computed and observed sensible heat flux during 5, 12 and 22 April 2010 is shown in Figure 5.
It is noticed that the range of the computed sensible heat flux is $0.0 \mathrm{Wm}^{-2}$ to $320 \mathrm{Wm}^{-2}$ and the observed sensible heat flux range is $-10 \mathrm{Wm}^{-2}$ to $200 \mathrm{Wm}^{-2}$ on 5 April (Fig. 5a).
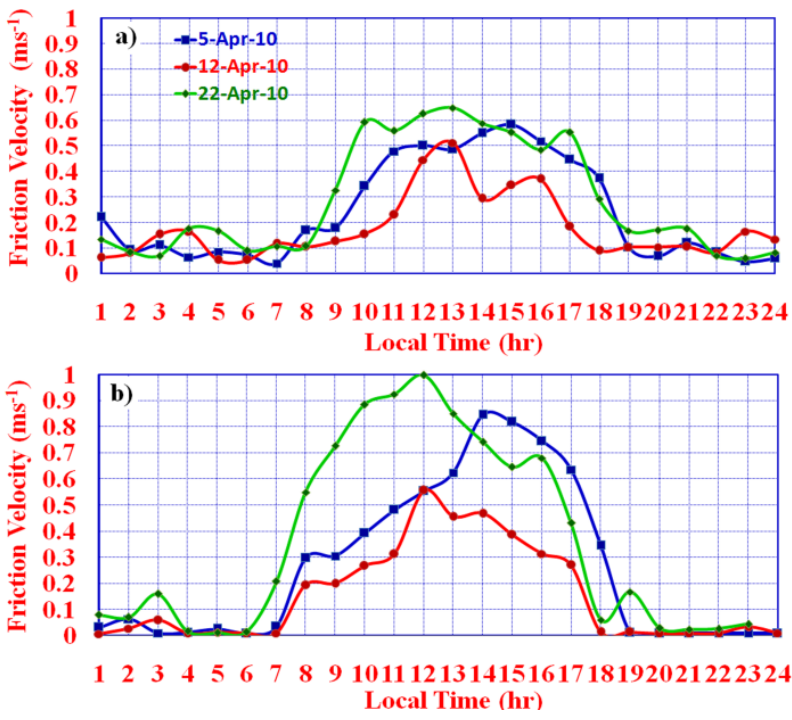

Figure 4: Comparison of computed and observed friction velocity $\left(\mathrm{ms}^{-1}\right)$ for (a) Observed (b) Computed respectively.

The computed sensible heat flux values show slight overestimation during day time and slight under-estimation during night time compared to observed values (Fig 5b). The computed and observed sensible heat flux ranges are $0.0 \mathrm{Wm}^{-}$ 2 to $175 \mathrm{Wm}^{-2}$ and $-25 \mathrm{Wm}^{-2}$ to $200 \mathrm{Wm}^{-2}$ on 12 April (Fig. $5 \mathrm{a} \& \mathrm{~b}$ ), Computed and observed sensible heat fluxes are in good agreement during day and night time on 12 April 2010. Whereas, the range of the computed and observed sensible heat fluxes on 22 April 2010 (Fig. 5a) are respectively $-5 \mathrm{Wm}$ 2 to $370 \mathrm{Wm}^{-2}$ and $-5 \mathrm{Wm}^{-2}$ to $220 \mathrm{Wm}^{-2}$. The computed sensible heat flux on 22 April 2010 over-estimated compared to observed sensible heat flux and in day time and night time.
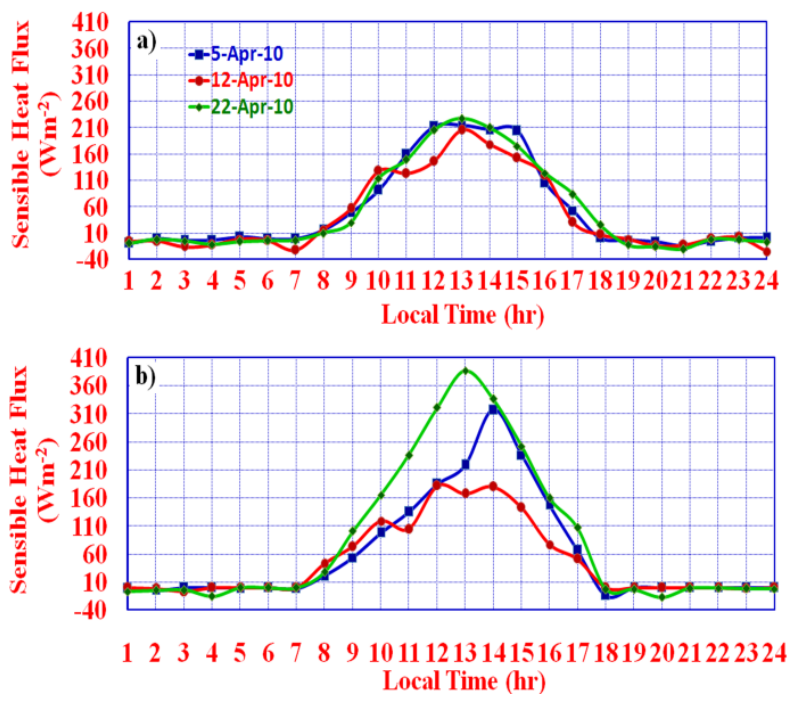

Figure 5: Comparison of computed sensible heat flux $\left(\mathrm{Wm}^{-2}\right)$ with observations for (a) Observed (b) Computed respectively.

Observations revealed well defined diurnal variability of sensible heat flux during a drier atmosphere as seen in all three days. Computed sensible heat flux is found to over- 
estimate the observed maximum on 5 and 22 April 2010 where as under-estimated on 12 April 2010. Overall the computed fluxes are in agreement with observed values. The variation sensible heat flux suggests moderate to strong turbulence during day time and weak turbulence during night time during the study period.

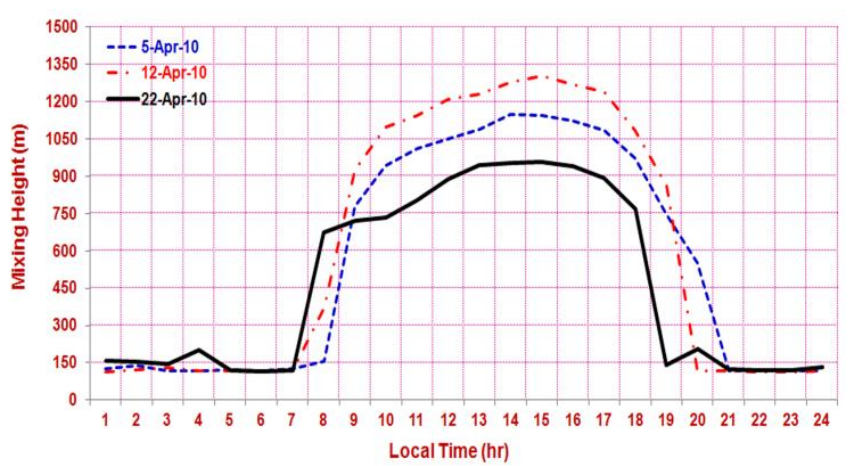

Figure 6: Diurnal variation of mixing height $(m)$ on 5, 12 and 22 April 2010.

Estimated mixing height during 5, 12 and 22 April 2010 are shown in Fig. 6. A maximum mixing height of $1250 \mathrm{~m}, 1100$ $\mathrm{m}$ and $950 \mathrm{~m}$ are noticed on 12, 5 and 22 April 2010 respectively.

\subsection{Comparison of Ground Level \\ Concentrations (GLCs) of Pollutants}

The GLCs of $\mathrm{NO}_{\mathrm{X}}$ were predicted using AERMOD in which, the boundary layer parameters (surface friction velocity, surface sensible heat flux, Monin-Obukhov length and inversion -mixing height) determined using the flux profile relationships in addition to the tower based micrometeorological data are used as input. Volume source is added at the monitoring location (Albert Ekka Chowk) which is located $6 \mathrm{~km}$ in west direction from the industry considered in the present study. The concentrations were computed over an area of $20 \mathrm{~km} \mathrm{x} 20 \mathrm{~km}$ with the industrial area at the centre of the region. The total area is divided into 1681 grids with each grid having a distance of 500 meter. The results are presented in the form of 24 hourly concentrations in $\mu \mathrm{gm}^{-3}$.

\subsubsection{Comparison of 24 hourly GLCs \\ Industrial Source Alone}

The 24 hourly concentrations of $\mathrm{NO}_{\mathrm{X}}$ computed using AERMOD is compared with the observations at Albert Ekka Chowk for 3, 5, 8, 12, 15, 19 and 22 April 2010 are given in Table 3. The comparison shows that the GLCs of $\mathrm{NO}_{\mathrm{X}}$ predicted by AERMOD are varying from $0.65 \mu \mathrm{gm}^{-3}$ (19 April

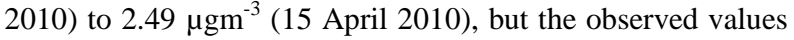
are high in magnitude compared to the predicted values. The reason for low values of predicted GLCs to that of observations is due to non inclusion of domestic fuel burning and vehicles traffic in the models.

To account for vehicular emissions at the receptor, the model is run with industrial as well as vehicular emission during the study period and is compared against observations from Albert Ekka Chowk, is described in the following section.
Table 2: Comparison of NOx 24 hourly concentrations predicted by AERMOD with observed values during the study period (April 2010) over Ranchi.

\begin{tabular}{|c|c|c|c|}
\hline $\begin{array}{c}\text { Serial } \\
\text { No. }\end{array}$ & Date & \multicolumn{2}{|c|}{$\begin{array}{c}\text { Concentration of NOx } \\
\left(\square \mathbf{g m}^{\mathbf{3}}\right)\end{array}$} \\
& & \multicolumn{2}{|c|}{} \\
\cline { 3 - 4 } & & AERMOD & Observed \\
\hline 1 & 3 April 2010 & 1.54 & 32.9 \\
\hline 2 & 5 April 2010 & 0.75 & 33.3 \\
\hline 3 & 8 April 2010 & 1.19 & 34.3 \\
\hline 4 & 12 April 2010 & 1.07 & 35.2 \\
\hline 5 & 15 April 2010 & 2.50 & 34.2 \\
\hline 6 & 19 April 2010 & 0.66 & 34.2 \\
\hline 7 & 22 April 2010 & 1.20 & 35 \\
\hline
\end{tabular}

\section{Including Industrial and vehicular sources}

The 24 hourly GLCs of $\mathrm{NO}_{\mathrm{X}}$ as 24 hourly averages are computed using AERMOD for 5, 12 and 22 April 2010. These three days were chosen based on the meteorological features.
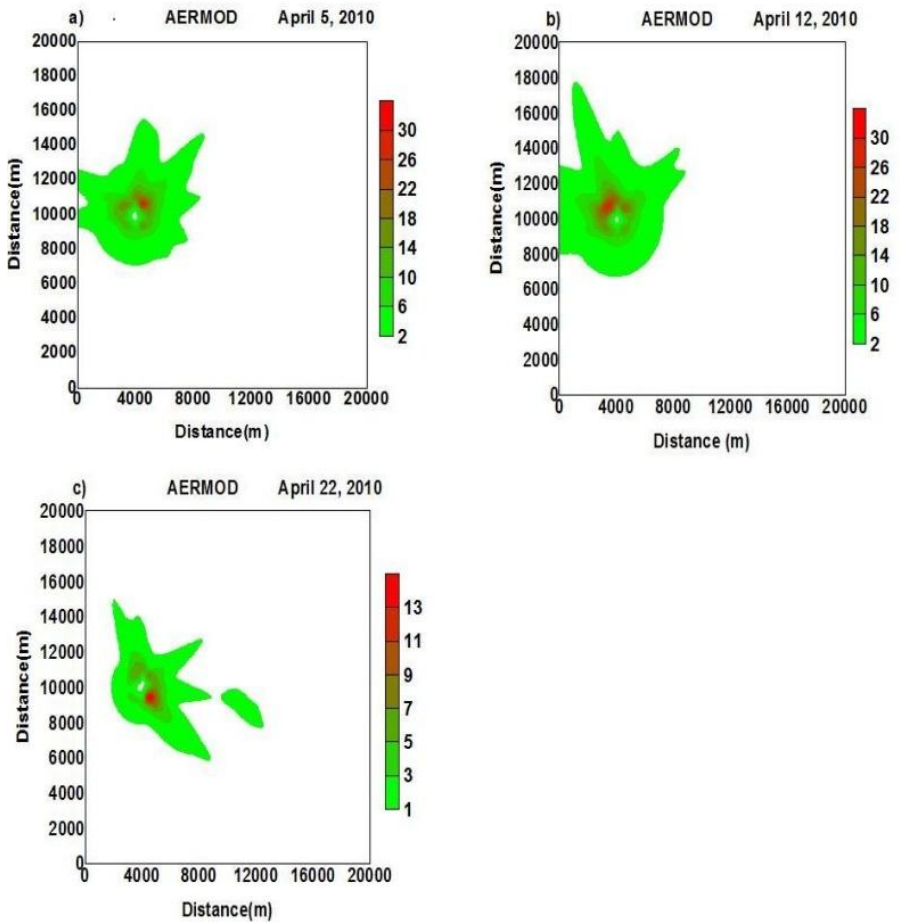

Figure 7: Spatial distribution of $\mathrm{NO}_{\mathrm{X}}$ concentrations obtained from AERMOD over Ranchi for (a) 5 April, (b) 12 April and (c) 22 April, 2010 respectively.

The incremental GLCs of $\mathrm{NO}_{\mathrm{X}}$ computed using AERMOD due to the emission from industrial complex and volume sources (vehicular traffic) are shown in Figures 7(a, b and c) receptively for days 5, 12 and 22 April 2010. vehicular emissions are considered.

The maximum incremental GLCs of $\mathrm{NO}_{\mathrm{X}}$ (Fig. 7a) are found to be very close to the monitoring location and in NW and NNW direction on 5 April 2010. However on 12 April 2010 the maximum incremental GLCs of $\mathrm{NO}_{\mathrm{X}}$ (Fig. 7b) are found to occur near the monitoring location and in NW and WSW 
direction. However on 22 April 2010 the maximum concentration is observed in the SE direction to the monitoring location where

Figure 8 is shows the comparison of $\mathrm{NO}_{\mathrm{X}}$ concentration obtained from the models with observations on 3, 5, 8, 12, 15, 19, and 22 of April 2010. AERMOD show good agreement with the observed values on 3, 5 and 12 compared to the rest of the days, during which AERMOD is under-predicted with respect to observations.

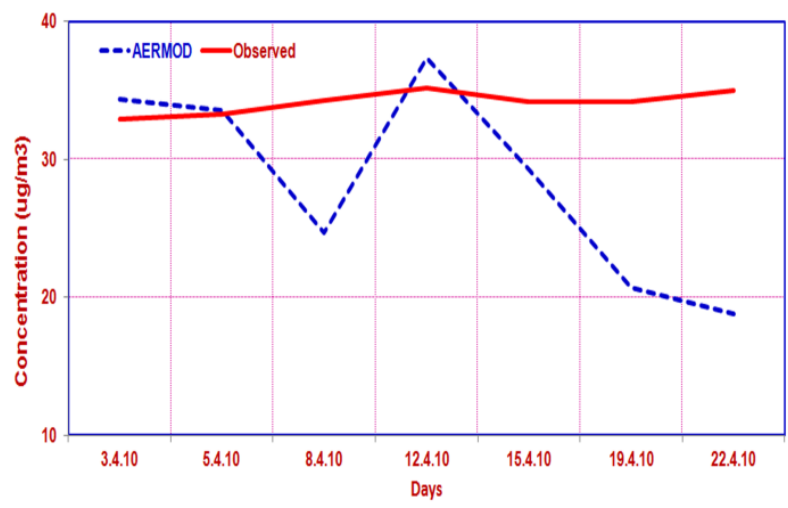

Figure 8: Comparison of $\mathrm{NO}_{\mathrm{X}}$ concentration estimated using AERMOD with observed values of Albert Ekka Chowk

From these results it is observed that AERMOD is underpredicting in the case wherein industrial sources only considered. This may be due to the fact that the computed concentration is very less compared to the observed values because observed value is inclusive of local sources such as vehicular traffic at the receptor considered in the present study. However, by considering vehicular sources along with industrial sources showed AERMOD performed better. This is clearly seen in the validation of AERMOD predicted GLCs with those observed GLCs at Albert Ekka Chowk.

\section{CONCLUSIONS}

In the present study an attempt has been made to understand the dispersion of air pollution by employing a dispersion model namely AERMOD over Ranchi during pre-monsoon period of 2010. It is observed that the model show distinct variations of spatial concentration from day to day. Validation of predicted GLCs with the observations without considering the volume sources reveals that the model is largely underpredicted the magnitudes due to the consideration of industrial sources alone. After incorporation of the volume sources due to vehicular transport, it is seen that AERMOD has provided reasonable pollutant concentration distribution. The reason could be attributed to the fact that AERMOD uses the biGaussian distribution during the day time convective conditions. This study clearly demonstrates the AERMOD having explicit boundary layer dynamics could able to provide better estimates of pollutant dispersion. The present study concludes that AERMOD model would be better option for dispersion modeling studies.

\section{ACKNOWLEDGMENTS}

Mr Rahul Boadh would like to acknowledge the Indian Institute of Technology Kharagpur for providing fellowship to conduct $\mathrm{PhD}$ work. We would like to express sincere thanks to Jharkhand Pollution Control Board and Mr. R.N. Kaysayp
(Board analysist) to provide the observation data for study period. The authors are thankful to Dr. S.R. Wate, Director, CSIR - National Environmental Engineering Research Institute (NEERI), Nagpur for encouraging the work. We would like to express our sincere thanks to Prof. N.C. Mahanty and Dr Manoj Kumar, BITS Mesra, Ranchi for providing the micro-meteorological tower observations. Thanks to Dr. V.V.S.N. Pinaka Pani for providing the necessary data and informations.

\section{REFERENCES}

[1] WHO, (1997). Health and Environment in Sustainable Development, Geneva, World Health Organization

[2] Daly, A. and P. Zannetti. (2007), an Introduction to Air Pollution-Definitions, Classifications, and History. Chapter 1 of AMBIENT AIRPOLLUTION (P. Zannetti, D. Al-Ajmi, and S. Al-Rashied, Editors). Published by The Arab School for Science and Technology (ASST), (http://www.arabschool.org.sy) and The EnviroComp Institute (http://www.envirocomp.org/).

[3] Goyal P., Rama Krishna, T.V.B.P.S. (2002), Dispersion of pollutants in convective low wind: a case study of Delhi, Atmospheric Environment, Vol. 36, pp. 2071-2079.

[4] Mehdizadeh F. and Rifai H.S. (2004), -Modeling point source plume at high altitudes using a modified Gaussian modelll Atmos. Environ., Vol. 38 page no. 821-831.

[5] Rama Krishna T.V.B.P.S., Reddy M.K., Reddy R.C. and Singh R.N. (2004), Assimilative capacity and dispersion of pollutants due to industrial sources in Visakhapatnam bowl area. Atmospheric Environment, Vol. 38, pp. 67756787.

[6] Rama Krishna T.V.B.P.S., Reddy M.K., Reddy R.C., Singh R.N. (2005), Impact of an industrial complex on the ambient air quality: case study using a dispersion model, Atmospheric Environment, Vol. 39, pp. 53955407.

[7] Jesse L., Cristiane L., Michael A. (2000), User Guide ISCAERMOD View Volume 1st and Volume 2nd, Lakes Environmental Pt. Ltd., Ontario, Canada.

[8] Hall D.J., Spanton A.M., Dunkerley F., Bennett M., Griffiths R.F. (2002), A Review of Dispersion Model Inter-comparison Studies Using ISC, R91, AERMOD and ADMS, R\&D Technical Report, pp. 353.

[9] The, J., and Hilverda, M. (2003), Provision of services to develop Guidance for air dispersion modeling, ministry of the environment, project no. ssb-034875.

[10] Kho, W. L. F., Sentian, J., Radojevi, M., Ton, C. L., Law, P. L. and Halipah, S. (2007), computing simulation versus observed $\mathrm{NO}_{2}$ and $\mathrm{SO}_{2}$ emitted from elevated point source complex. Int. J. of Environ. Sci. Tech. Vol. 4(2), pp. 215-222.

[11] El-Fadel M., Abi-Esber L., and Ayash T. (2009) Managing emissions from highly industrialized areas: Regulatory compliance under uncertainty. Atmospheric Environment Vol. 43, pp. 5015-5026.

[12] Manju Mohan, Shweta Bhati and Archana Rao (2010), Application of air dispersion modeling for exposure assessment from particulate matter pollution in Mega City Delhi, Asia-Pac. J. Chem. Eng. Vol. 6, page no. 85-94. 
[13] Carbonell, L. M. T., Gacita, M. S., Oliva, J. de J. R., Garea, L. C., Rivero, N. D. and Ruiz, E. M. (2010), Methodological guide for implementation of the AERMOD system with incomplete local data. Atmospheric Pollution Research Vol. 1, pp. 102-111.

[14] Biswas J., Upadhyay, E., Nayak, M., and Yadav, A. K. (2011), An Analysis of Ambient Air Quality Conditions over Delhi, India from 2004 to 2009, Atmospheric and Climate Sciences Vol. 1, pp. 214-224.

[15] Census of India (2001): Data from the 2001 Census, including cities, villages and towns (Provisional). Census Commission of India, Archived from the original on 2004-06-16. Retrieved 2008-11-01.

[16] Tyagi, B. and Satyanarayna, A.N.V. (2010), Modeling of Soil Surface Temperature and Heat Flux during Premonsoon season at two Tropical Stations, Journal of Atmospheric and Solar-Terrestrial Physics, Vol. 72, pp. 224-233.

[17] Van Ulden, A. P. and Holtslag, A. A. M.: 1985, 'Estimation Atmospheric Boundary Layer Parameters for Diffusion Applications', J. Climate Appl. Meteorol. 24, 1196-1207.

[18] Arya, S. P. S.: 1988, Introduction to Micrometeorology, Academic Press, 307pp

[19] Stull, R.: 1988, An Introduction to Boundary Layer Meteorology, Kluwer academic publishers, Netherlands, pp 666

[20] Businger, J.A., Wyngaard, J.C., Izumi, Y., and Bradley, E.F., 1971. Flux Profile Relationships in the Atmospheric Surface Layer. Journal of Atmospheric Science 28, 181-189

[21] Beljaars, A. C. M., and A. A. M. Holtslag, 1991. Flux parameterization over land surfaces for atmospheric models. J. Appl. Meteor., 30, 327-341
[22] Sharan, M., T. V. B. P. S. Rama Krishna and Aditi, 2003: Surface-Layer Characteristics in the Stable Boundary Layer with Strong and Weak Winds. Boundary-Layer Meteorology, 108, 257-288.

[23] Holzworth G.C., 1967. Mixing depth, wind speed and air pollution potential for selected locations in the United States. Applied Meteorology, 125-129.

[24] Burba, G. and D. Anderson, 2007. Introduction of the Eddy Covariance method: general guidelines and conventional workflow. LI-COR Biosciences. Copyright 2005-2007 LI-COR, Inc

[25] Tyagi, B., Satyanarayana, A.N.V., Kumar, M., and Mahanti, N.C., 2012. Surface energy and radiation budget over a tropical station: An Observational study, Asia-Pacific Journal of Atmospheric Science, 48(4), 411421

[26] Arai, 2007. Draft report on "Emission Factor development for Indian Vehicles" as a part of Ambient Air Quality Monitoring and Emission Source Apportionment Studies, p. 1-94.

[27] Cimorelli, A. J., Perry, G. S., Venkatram, A., Weil, J. C., Paine R. J., Wilson R. B., Lee, R. F., Peters, W. D., and Brode R. W., 2004. AERMOD: A Dispersion Model for Industrial Source Applications. Part 1: General model formulation and boundary layer characterization, Journal of Applied meteorology Vol. 44, pp. 682-693.

[28] EPA, (2004), AERMOD User's Guide for the AMS/EPA regulatory model - AERMOD (EPA-454/B-03-001, September.

[29] Manju, N., Balakrishnan, R., Mani, N., 2002. Assimilative capacity and pollutant dispersion studies for the industrial zone of Manali. Atmospheric 